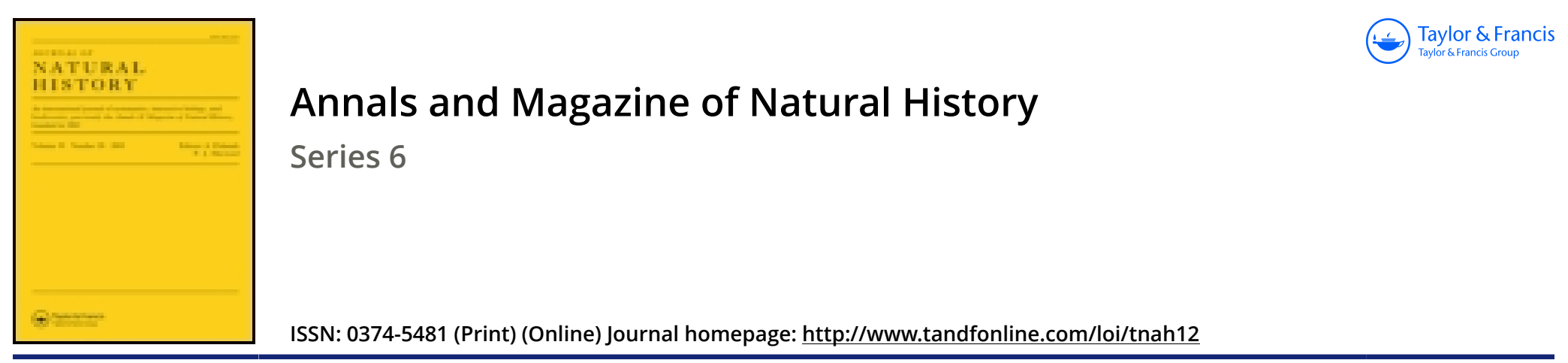

\title{
The fauna of the Eifel-Maare
}

\section{Dr. Otto Zacharias}

To cite this article: Dr. Otto Zacharias (1889) The fauna of the Eifel-Maare, Annals and Magazine of Natural History, 3:15, 292-292, DOI: 10.1080/00222938909460333

To link to this article: http://dx.doi.org/10.1080/00222938909460333

$$
\text { 册 Published online: } 09 \text { Oct } 2009 .
$$

Submit your article to this journal

LII Article views: 4

Q View related articles 두 
Note on Antedon pumila and A. incommoda. By F. Jefretex Beld.

On p. 157 of the 'Alert' Report* I stated that the second pinnule of Artedon pumila was longer than the first; as a matter of fact it is the first that is longer than the second. This error has proved to be more than usually unfortunate, for it led Dr. H. Carpentert to assign it to a group of species with which it has no special relation, and to my institution $\neq$ of a new species, A. incommoda, for examples of what are really $A$. pumila. I regret, moreover, to learn that it has caused some trouble to the ardent naturalists who are now working so activcly in Australia.

The Futuna of the Eifel-Metaie. By Dr. Otro Zacharias.

At the suggestion of Prof. F, Leydig the author made an excursion into the region of the Eifel in order to cxamine some of the so-called " maare."

In the Gemündener Maar, near Dann, he ascertained the presonco of a pelagic fauna, although the lake is but small, measuring only 8.3 hectares. The pelagic fauna consisted of swarms of a cinnabarred Diaptomus (D. pyymecus, Vosseler, sp. n.), of innumerable specimens of Asplanchna helvetica, of colonies of Conochilus volvox, and isolated examples of Daphnella brachyura, Liér. In the littoral zone there are other species of Daphniidœ, some Lynceidæ, and various species of Protozon. Among them several species of $\mathrm{Hy}$ drachnidæ, especially Hygrobates longipalpis, Herm., occur in abundance.

The Laacher See, which is only a large " maar," also contains a pelagic fauna, which, however, includes other species than those of the small Gemündener Maar. Here Daphriac vitrea, Kurz, occurred, among numerous examples of Polyarthra platyptera, Ehr., Anurcea longispina, Conochilus volvox, and the Dinoflagellate Ceratium hirundinella, Bergh.

The author remarks upon the fact that in such confined craterlakes as the "maars" of the Eifel a pelagic fauna has been established. He regards this as an evidence of transportation by flying organisms, although in many cases the wind may come into operation, by carrying encysted Protozoa, for example, high into the air, and thus transplanting them into distant waters. Water-beetles also he regards as important agents in the transfer.-Biol. Centralblatt, November 15, 1888, p. 574 .

* London, 1884 .

† 'Challenger' Reports, part lx. p. 193.

$\ddagger$ Ann. \& Mag. N. H. (6) ii. p. 404. 